\title{
DETECÇÃO DE FUNGOS MICORRÍZICOS ARBUSCULARES EM RAÍZES DE CAFEEIRO E DE CROTALÁRIA CULTIVADA NA ENTRELINHA ${ }^{1}$
}

\author{
ARNALDO COLOZZI FILHO² e ELKE JURANDI BRAN NOGUEIRA CARDOSO ${ }^{3}$
}

\begin{abstract}
RESUMO - Avaliou-se a ocorrência de fungos micorrízicos arbusculares (FMAs) no solo rizosférico e nas raízes de cafeeiro (Coffea arabica L.) e de Crotalaria breviflora DC., cultivada na entrelinha como adubo verde. Amostras de solo rizosférico e raízes foram coletadas em julho de 1997, em parte de um experimento de longa duração conduzido no campo pelo Instituto Agronômico do Paraná, no município de Mirasselva, PR. Determinou-se a diversidade de FMAs, por meio da identificação morfológica dos esporos, a frequiência de ocorrência de populações de FMAs por meio da contagem direta de esporos no solo, e a colonização radicular. Extraiu-se DNA de raízes de cafeeiro colonizadas e não-colonizadas e de esporos de Acaulospora longula e Scutellospora gilmorei, coletados na rizosfera, realizando-se a PCR ("Polimerase chain reaction") com primers ITS ("Internal transcribed spacer") e comparando os perfis de bandas obtidos. O cultivo de crotalária na entrelinha do cafeeiro aumentou a concentração de esporos de FMAs na rizosfera do cafeeiro. A crotalária e o cafeeiro estimularam populações diferentes de FMAs. O gênero Acaulospora predominou na rizosfera do cafeeiro, e Scutellospora e Gigaspora na rizosfera da crotalária. Usando técnicas moleculares, foi possível caracterizar FMAs na rizosfera e nas raízes colonizadas do cafeeiro. O fungo micorrízico Scutellospora gilmorei, de ocorrência comum em cafeeiro e crotalária, não foi encontrado colonizando as raízes do cafeeiro. O uso de técnicas moleculares pode auxiliar no estudo da dinâmica populacional de FMAs no campo.
\end{abstract}

Termos para indexação: Coffea arabica, Crotalaria breviflora, relação planta-solo, rizosfera, simbiontes, fungos.

\section{DETECTION OF ARBUSCULAR MYCORRHIZAL FUNGI IN ROOTS OF COFFEE PLANTS AND CROTALARIA CULTIVATED BETWEEN ROWS}

\begin{abstract}
The sporulation and occurrence of arbuscular mycorrhizal fungi (AMF) was evaluated in the coffee trees (Coffea arabica L.) and Crotalaria breviflora DC. rhizosphere and roots. C. breviflora was intercropped for green manure of the coffee plants. Samples of rhizosphere soil and roots were collected in July of 1997 in a long-time experiment localized at the Instituto Agronômico do Paraná (IAPAR), in Mirasselva, PR, Brazil. The AMF diversity was determined through the morphologic identification of spores, the AMF occurrence frequency by the direct counting of spores in the soil, and the root colonization. To identify AMF in coffee roots, DNA from spores collected in the rhizosphere and from colonized coffee roots was extracted and used for PCR (Polimerase chain reaction) with ITS (Internal transcribed spacer) primers, comparing the obtained bands. The legume intercropping cultivation increased the spores concentration of AMF in the soil. Coffee and C. breviflora plants stimulated populations of different AMF in their rhizospheres. Scutellospora spp. and Gigaspora spp. were more abundant at the legume rhizosphere. Acaulospora spp. occurred more often in coffee plant rhizospheres. Using molecular techniques, it was possible to characterize AMF in the rhizosphere and in the colonized roots of the coffee plants. Scutellospora gilmorei, of common occurrence in coffee plants and $C$. breviflora, was not found colonizing the roots of coffee plants. Molecular techiniques can be of great help in the study of AM fungal dynamics in the field.

Index terms: Coffea arabica, Crotalaria breviflora, plant soil relations, rhizosphere, symbionts, fungi.
\end{abstract}

${ }^{1}$ Aceito para publicação em 14 de dezembro de 1999. Extraído da tese de doutorado apresentada pelo primeiro autor à ESALQ-USP, Piracicaba, SP. Parcialmente financiado pelo CNPq.

${ }^{2}$ Eng. Agrôn., Dr., Instituto Agronômico do Paraná (IAPAR), Caixa Postal 481, CEP 86001-970 Londrina, PR. E-mail: acolozzi@pr.gov.br

${ }^{3}$ Eng. Agrôn., Ph.D., Prof. Titular, Dep. de Solos, ESALQ, USP, Caixa Postal 09, CEP 13418-900 Piracicaba, SP. E-mail: ejbncard@carpa.ciagri.usp.br

\section{INTRODUÇÃO}

As micorrizas arbusculares são associações simbiotróficas entre fungos da ordem Glomales e raízes da maioria das plantas vasculares. Atuam como um complemento do sistema radicular da planta hospedeira, capaz de aumentar a absorção de P e outros nutrientes, promover proteção contra 
patógenos e desencadear no hospedeiro diversos outros efeitos ainda não de todo compreendidos.

Esta simbiose é particularmente importante para o cafeeiro, porque este apresenta elevada dependência aos fungos micorrízicos arbusculares (FMAs) na fase de produção de mudas (Siqueira \& Colozzi Filho, 1986). Entretanto, as informações sobre a ocorrência de FMAs em cafeeiros não-inoculados em produção mostram a predominância de espécies indígenas de baixa eficiência simbiótica (Fernandes, 1987; Balota \& Lopes, 1996a). Espécies selecionadas eficientes normalmente não ocorrem no campo (Lopes et al., 1983), e quando introduzidas via inoculação, têm dificuldade de permanecer no agrossistema (Balota \& Lopes, 1996b). Por meio do manejo das culturas é possível aumentar o potencial de inóculo natural do solo (Baltruschat \& Dehne, 1988) e a diversidade de espécies de FMAs, promovendo a sustentabilidade do agrossistema (Bethlenfalvay \& Linderman, 1992).

O estudo de ocorrência e dinâmica das populações de FMAs no solo é um desafio, dada a dificuldade de identificação destes fungos, tanto livres no solo como no interior das raízes. Estudos com culturas-armadilhas são difíceis de serem executados, e muitas vezes fornecem resultados não-conclusivos. Este desafio, entretanto, está sendo vencido com o auxílio de novas técnicas de biologia molecular. Estas técnicas têm permitido identificar fungos a partir de esporos coletados diretamente do campo e também identificar FMAs colonizando raízes de plantas.

Análises de fragmentos de restrição de DNA amplificados por PCR (Polimerase chain reaction) constituem uma ferramenta poderosa que permite a detecção de moléculas de ácidos nucléicos específicos presentes em pequenas quantidades (Steffan \& Atlas, 1991)e tem sido aplicada com sucesso na identificação de FMAs. O uso da PCR com primers que flanqueiam a região genômica do ITS (Internal transcribed spacer) (Redecker et al., 1997) ou mesmo primers específicos como os desenvolvidos para Glomus mosseae (Lanfranco et al., 1995) e para Scutellospora castanea (Zeze et al, 1996), tem permitido a identificação taxonômica destes fungos sem os problemas de variações nos caracteres morfológicos que dificultam a taxonomia tradicional. Estas técnicas também têm sido aplicadas como ferramenta auxiliar para a identificação de FMAs internamente às raízes (Bonito et al., 1995; Edwards et al., 1997).

Pesq. agropec. bras., Brasília, v.35, n.10, p.2033-2042, out. 2000
O objetivo deste trabalho foi estudar a esporulação, a freqüência de ocorrência e a composição das populações de FMAs na rizosfera do cafeeiro e da Crotalaria breviflora cultivada na entrelinha como adubo verde, e a colonização radicular do cafeeiro.

\section{MATERIAL E MÉTODOS}

Este estudo foi realizado em amostras de solo rizosférico e de raízes coletadas em um experimento de 12 anos de duração, conduzido no campo pelo Instituto Agronômico do Paraná (IAPAR), no município de Mirasselva, PR, com o objetivo de estudar os efeitos do cultivo intercalar de adubos verdes sobre as propriedades do solo e a produtividade do cafeeiro.

O experimento foi instalado em uma área de Latossolo Vermelho-Escuro distrófico (LEd), onde se cultiva o cafeeiro 'Catuaí Amarelo' nas linhas principais, e nas entrelinhas, as leguminosas leucena (Leucaena leucocephala Benth.), Crotalaria spectabilis Roth, C. breviflora DC., mucuna-cinzenta (Stizolobium cinereum Piper \& Tracy), mucuna-anã (Stizolobium deeringianum Bort.), amendoim-cavalo (Arachis hipogeae L.), e caupi (Vigna unguiculata Endl.) para fins de adubação verde. Como controle, cultiva-se o cafeeiro conduzido no limpo. O delineamento experimental foi o de blocos ao acaso, com três repetições.

No presente estudo, avaliou-se a micorrização apenas nos tratamentos sob efeito do cultivo da $C$. breviflora, considerando-se os efeitos positivos do cultivo desta leguminosa sobre a esporulação e a diversidade de espécies de FMAs, conforme relatados por Colozzi Filho (1999). Para tanto, em julho de 1997 coletaram-se amostras de solo e de raízes, na linha de cafeeiro conduzido com cultivo intercalar de $C$. breviflora, na linha de cultivo da C. breviflora, e na linha de cafeeiro conduzido sem cultivo intercalar (controle), constituindo três tratamentos.

Em cada local de amostragem foram coletadas três amostras compostas (uma por bloco) contendo aproximadamente $1 \mathrm{~kg}$ de solo rizosférico e raízes. As amostras foram compostas por quatro subamostras coletadas na profundidade de 0 a $20 \mathrm{~cm}$. No cafeeiro, as subamostras foram coletadas em quatro pontos eqüidistantes sob a projeção da copa e orientados para as direções norte, sul, leste e oeste. Na linha de plantio da crotalária, as subamostras foram coletadas em lados alternados (direito e esquerdo).

\section{Histórico da área e condução do experimento a campo}

O experimento foi instalado em 1988. O cafeeiro foi cultivado no espaçamento $4,0 \times 2,0 \mathrm{~m}$ por cova de duas 
plantas e cada parcela possuia 32 covas (4 linhas de 8 covas), sendo as 8 covas centrais a área útil da parcela. Anualmente, as leguminosas foram semeadas na primeira quinzena de outubro, sendo que a densidade de sementes variou de acordo com a espécie. Por ocasião da floração, que ocorre em épocas diferentes para cada espécie, as leguminosas foram cortadas, deixando-se os resíduos amontoados na área para cobertura do solo e decomposição. No controle foram feitas capinas manuais durante o ano, sempre que necessário.

Para correção da acidez do solo, foram realizadas duas calagens na área: a primeira, por ocasião da instalação do experimento, e a segunda, em 1997. Em ambas foram aplicadas duas toneladas de calcário dolomítico por hectare.

Anualmente, entre os meses de setembro a março, foram realizadas fertilizações com NPK sob a projeção da copa do cafeeiro, de modo a fornecer por cova $400 \mathrm{~g}$ de sulfato de amônio, $60 \mathrm{~g}$ de superfosfato triplo e $100 \mathrm{~g}$ de cloreto de potássio, com aplicações de $\mathrm{N}$ e K parceladas em quatro e duas vezes, respectivamente, e o P aplicado em dose única.

\section{Caracterização química das amostras de solo}

Do material amostrado (solo e raízes), $100 \mathrm{~g}$ de solo foram utilizadas para análises químicas de rotina $(\mathrm{pH}, \mathrm{C}$, $\mathrm{P}, \mathrm{K}, \mathrm{Ca}, \mathrm{Mg}$ e Al). Os resultados estão apresentados na Tabela 1. $\mathrm{O}$ pH foi determinado em solução de $\mathrm{CaCl}_{2}$ $0,01 \mathrm{~mol} \mathrm{~L}^{-1}$. P e $\mathrm{K}$ foram extraídos pelo extrator Mehlich-1. Os teores de $\mathrm{P}$ foram determinados por colorimetria, e os de $\mathrm{K}$, por fotometria de chama. $\mathrm{Ca}, \mathrm{Mg}$ e $\mathrm{Al}$ foram extraídos com $\mathrm{KCl} 1 \mathrm{~mol} \mathrm{~L}^{-1}$ e determinados por titulometria. $\mathrm{O}$ carbono orgânico foi extraído com $\mathrm{Na}_{2} \mathrm{Cr}_{2} \mathrm{O}_{7} 2 \mathrm{~mol} \mathrm{~L}^{-1}+\mathrm{H}_{2} \mathrm{SO}_{4} 5 \mathrm{~mol} \mathrm{~L}^{-1}$ e determinado por colorimetria.

\section{Esporos de FMAs}

Os esporos foram extraídos do solo por peneiramento úmido, conforme Gerdemann \& Nicolson (1963) e centrifugados em água a $3.000 \mathrm{rpm}$, por três minutos e em sacarose $50 \%$ a $2.000 \mathrm{rpm}$, por 2 minutos. Após a extração dos esporos, estes foram lavados por quatro vezes em água destilada estéril e então submetidos ao ultra-som por 30 segundos, na potência máxima, para eliminar esporos velhos e também partículas de solo e microrganismos contaminantes aderidos superficialmente. Em seguida foram lavados por quatro vezes em água destilada estéril.

Para as determinações qualitativas (identificação de espécies) e quantitativas (contagem), os esporos foram fixados com PVL (Polivinil-álcool) em lâminas microscópicas e observados em microscópio óptico composto. A identificação das espécies foi feita com base em critérios morfológicos, conforme Schenck \& Perez (1987) e Morton \& Benny (1990).

Para extração de DNA, esporos de Acaulospora longula e Scutellospora gilmorei, observados na rizosfera do cafeeiro, foram obtidos em uma nova extração e separados por espécie do restante da população de FMAs, sob microscópio estereoscópico (aumento de 80x) com luz refletida. Os esporos foram selecionados pela aparência externa, considerando-se a coloração uniforme, forma globosa regular e ausência de solo aderido externamente. Esporos com características discrepantes foram descartados.

O DNA foi extraído mediante a quebra de um único esporo em $5 \mu \mathrm{L}$ de água estéril, garantindo a liberação de todo seu conteúdo na água para formação do extrato cru, que foi rapidamente colocado no mix para a reação de PCR.

\section{Raízes}

Raízes do cafeeiro foram separadas do solo rizosférico em água corrente, e lavadas. Para a determinação da colonização radicular por FMAs, as raízes foram aquecidas a $60^{\circ} \mathrm{C}$ em $\mathrm{KOH} 10 \%$ por 10 minutos, para clarificação; lavadas em água destilada quatro vezes; acidificadas com $\mathrm{HCl} 1 \%$ por 2 minutos; e fervidas por 10 minutos em solução de glicerol ácido e azul de tripano 0,05\% (Phillips \& Hayman, 1970). A determinação da porcentagem de colonização radicular foi feita em microscópio estereoscópico,

TABELA 1. Características químicas do solo cultivado com cafeeiro e (Coffea arabica L.) e com crotalária (Crotalaria breviflora DC.) cultivada na entrelinha como adubo verde. Média de três repetições.

\begin{tabular}{lccccccc}
\hline Local $^{1}$ & $\mathrm{pH}$ & $\begin{array}{c}\text { Carbono } \\
\text { orgânico }\end{array}$ & $\mathrm{P}$ & $\mathrm{K}$ & $\mathrm{Ca}$ & $\mathrm{Mg}$ & $\mathrm{Al}$ \\
\hline Cafeeiro sem crotalária & 3,9 & $\left(\mathrm{~g} \mathrm{~kg}^{-1}\right)$ & $-----\left(\mathrm{mg} \mathrm{dm}^{-3}\right)----$ & $---1------$ & $\left(\mathrm{cmol}_{\mathrm{c}} \mathrm{dm}^{-3}\right)$ & ---------- \\
Cafeeiro com crotalária & 3,9 & 8,0 & 29,5 & 0,18 & 0,70 & 0,45 & 0,58 \\
Crotalária & 5,11 & 8,9 & 28,5 & 0,17 & 0,70 & 0,48 & 0,60 \\
\hline
\end{tabular}

${ }^{1}$ Amostras coletadas na projeção da copa do cafeeiro e na linha de cultivo da crotalária, na profundidade de 0 a $20 \mathrm{~cm}$. 
pelo método da placa quadriculada, segundo Giovannetti \& Mosse (1980).

Para tentar conhecer se esporos de ocorrência rizosférica comum colonizam ambas as plantas, quando cultivadas de modo intercalar, selecionaram-se raízes do cafeeiro cultivado com crotalária na entrelinha, para, por meio da extração do DNA e amplificação com primers ITS, tentar obter correspondência entre o padrão de bandeamento de DNA dos FMAs que colonizavam as raízes e o padrão de bandas obtido do DNA extraído de esporos na rizosfera. Utilizaram-se $50 \mathrm{mg}$ de raízes colonizadas e $50 \mathrm{mg}$ de raízes não-colonizadas coletadas nas amostras compostas representativas de cada repetição, para extração do DNA. As raízes foram selecionadas em microscópio composto, sendo a colonização evidenciada pela presença de arbúsculos ou vesículas coradas em azul de tripano. $\mathrm{Na}$ seleção procurou-se amostrar diferentes tipos de micélio interno (fino e grosso) ou a presença de vesículas. O DNA foi extraído segundo metodologia proposta por Bonito et al. (1995), onde, para a retirada de água, as raízes foram centrifugadas a $12.000 \mathrm{~g}$ durante 1 minuto e então, maceradas em $800 \mu \mathrm{L}$ de tampão de extração (Tris$\mathrm{HCl} 1 \mathrm{M}, \mathrm{pH} 8,5)$. Ao extrato foi adicionada a resina Chelex 100, a uma concentração final de $5 \%$ do volume do tampão de extração. A mistura foi homogeneizada em vórtex e então fervida em banho-maria por 15 minutos. A resina e os fragmentos das raízes foram removidos por centrifugação a $12.000 \mathrm{~g}$ por 30 segundos, coletando-se o sobrenadante. $\mathrm{O}$ material coletado foi imediatamente utilizado ou armazenado a $-20^{\circ} \mathrm{C}$. Para a PCR foram feitas séries de diluições em água com concentrações de 1:10 a 1:10.000 (vol:vol).

\section{PCR de esporos e raízes}

A reação da PCR consistiu de $5 \mu \mathrm{L}$ do extrato cru contendo DNA de esporos ou raízes, adicionados ao mix para um volume final de $50 \mu \mathrm{L}$. A concentração final na reação foi de $125 \mu \mathrm{M}$ de cada dNTP, 20 pmol de cada primer, 7,5 $\mathrm{mM}$ de $\mathrm{MgCl}_{2}, 1,5$ unidades de Taq polimerase Goldstar (Eurogentec, Seraing, Bélgica), sendo o tampão fornecido com a enzima e usado nas concentrações conforme indicações do fabricante. Os primers ITS 4 (5'-TCCTCCGCTTATTGATATGC-3’) e ITS 5 (5‘GGAAGTAAAAGTCGTAACAA GG-3') (MWGBiotech, Ebersberg, Alemanha) foram utilizados combinados.

O DNA ribossomal da região ITS foi amplificado por um termociclador Perkin-Elmer System 2400, programado para $95^{\circ} \mathrm{C}$ por três minutos para desnaturação inicial, 40 ciclos de 1 minuto a $94^{\circ} \mathrm{C}$ para desnaturação, 40 segun-

Pesq. agropec. bras., Brasília, v.35, n.10, p.2033-2042, out. 2000 dos a $50^{\circ} \mathrm{C}$ para anelamento, 1 minuto a $72^{\circ} \mathrm{C}$ para extensão e 5 minutos a $72^{\circ} \mathrm{C}$ para extensão final. Em todos os experimentos foram usados tratamentos-controle, em que nenhum DNA foi colocado. Todos os tubos e materiais utilizados na composição das soluções e no manuseio foram esterilizados.

Os produtos obtidos foram separados por eletroforese em gel de agarose $1,4 \%$. Os fragmentos de DNA resultantes foram visualizados mediante coloração com brometo de etídeo e fotografados sob luz U.V.

Os dados de produção de esporos foram tabulados e analisados segundo sua distribuição de frequiência.

\section{RESULTADOS E DISCUSSÃO}

A ocorrência, a esporulação no solo e a freqüência de ocorrência de FMAs na rizosfera do cafeeiro e de $C$. breviflora são apresentadas na Tabela 2. Foram observadas dez espécies de FMAs na área, sendo cinco no cafeeiro com crotalária, cinco na crotalária e sete no cafeeiro sem adubo verde. No cafeeiro com crotalária ocorreram Scutellospora gilmorei, Acaulospora scrobiculata, A. longula, Acaulospora sp. e Glomus diaphanum, com maior ocorrência de esporos do gênero Acaulospora (60\% sobre o total). Na crotalária, a população foi composta por S. gilmorei, Gigaspora margarita, G. decipiens, A. scrobiculata e A. appendicula, com maior freqüência de ocorrência de esporos dos gêneros Scutellospora e Gigaspora, que, somados, representaram $81 \%$ do total (Tabela 2). No cafeeiro sem adubo verde, foram observadas S. gilmorei, S. heterogama, A. scrobiculata, A. longula, A. appendicula, A. spinosa e $G$. diaphanum, sendo Acaulospora o gênero de maior frequiência (61\%).

A. spinosa, S. heterogama, A. longula, Acaulospora sp. e $G$. diaphanum foram observadas somente em cafeeiro, sendo $A$. longula com frequiência de ocorrência superior à de todos os outros componentes das populações $(36,3 \%)$. G. margarita e G. decipiens foram observadas apenas na crotalária. Entretanto, nesta, a espécie de maior ocorrência foi S. gilmorei $(45,3 \%)$, que também foi observada no cafeeiro com até $19,3 \%$ de freqüência de ocorrência (Tabela 2). A esporulação dos FMAs na rizosfera do cafeeiro com adubo verde e na rizosfera da crotalária foi maior que no controle.

Os produtos da PCR de DNA genômico de A. longula, observado apenas na rizosfera do cafe- 
TABELA2. Ocorrência, esporulação no solo (E) e freqüência de ocorrência (F) de fungos micorrízicos arbusculares em solo cultivado com cafeeiro (Coffea arabica L.) intercalado ou não com crotalária (Crotalaria breviflora) cultivada na entrelinha como adubação verde, em experimento de longa duração conduzido no campo. IAPAR, Mirasselva, PR. Média de três repetições.

\begin{tabular}{|c|c|c|c|c|c|c|}
\hline \multirow{2}{*}{$\begin{array}{l}\text { Fungos } \\
\text { micorrízicos }\end{array}$} & \multicolumn{2}{|c|}{ Cafeeiro com crotalária } & \multicolumn{2}{|c|}{ Crotalária } & \multicolumn{2}{|c|}{ Cafeeiro sem crotalária } \\
\hline & $E^{1}$ & $\mathrm{~F}^{2}(\%)$ & $E$ & $\mathrm{~F}(\%)$ & $\mathrm{E}$ & $\mathrm{F}(\%)$ \\
\hline Scutellospora gilmorei & 26 & 19,3 & 48 & 45,3 & 3 & 4,9 \\
\hline S. heterogama & - & - & - & - & 3 & 4,9 \\
\hline Gigaspora margarita & - & - & 9 & 8,5 & - & - \\
\hline G. decipiens & - & - & 29 & 27,3 & - & - \\
\hline Acaulospora scrobiculata & 26 & 19,3 & 9 & 8,5 & 3 & 4,9 \\
\hline A. appendicula & - & - & 11 & 10,4 & 7 & 11,3 \\
\hline A. longula & 49 & 36,3 & - & - & 13 & 21,0 \\
\hline A. spinosa & - & - & - & - & 14 & 22,3 \\
\hline Acaulospora sp. & 6 & 4,4 & - & - & - & - \\
\hline Glomus diaphanum & 28 & 20,7 & - & - & 19 & 30,7 \\
\hline Total & 135 & 100,0 & 106 & 100,0 & 62 & 100,0 \\
\hline
\end{tabular}

eiro, e de S. gilmorei, observado na rizosfera das duas plantas mas com freqüência de ocorrência maior na crotalária, são apresentados na Fig. 1. Observou-se fragmentos de DNA de peso molecular diferentes nas duas espécies de FMAs estudadas. A. longula apresentou fragmentos amplificados de aproximadamente 580 bases pares (bp), e $S$. gilmorei, de aproximadamente $540 \mathrm{bp}$. As amplificações obtidas de esporos diferentes da mesma espécie de FMA apresentaram bandas com o mesmo peso molecular, mas de intensidades diferentes (Fig. 1).

Testes de diluição com extratos crus, obtidos de fragmentos de raízes de cafeeiro colonizadas e nãocolonizadas mostraram que, no extrato obtido e nas condições do experimento, a melhor diluição para a obtenção de produtos de amplificação de PCR usando primers ITS 4 e 5 foi a diluição 1:100 (Fig. 2). Entretanto, a frequiência de amplificações positivas foi baixa. Extratos não diluídos ou diluídos de 1:1000 não apresentaram amplificações. Em todos os PCR realizados, não se observaram amplificações em extratos de raízes não-colonizadas e na testemunha (sem DNA).

Produtos da amplificação de fragmentos de DNA de esporos de A. longula e de raízes de cafeeiros colonizadas, usando primers de ITS 4 e 5 combinados, mostraram padrão de bandeamento semelhante, e este padrão foi diferente do observado nos esporos de $S$. gilmorei (Fig. 3). Fragmentos de DNA

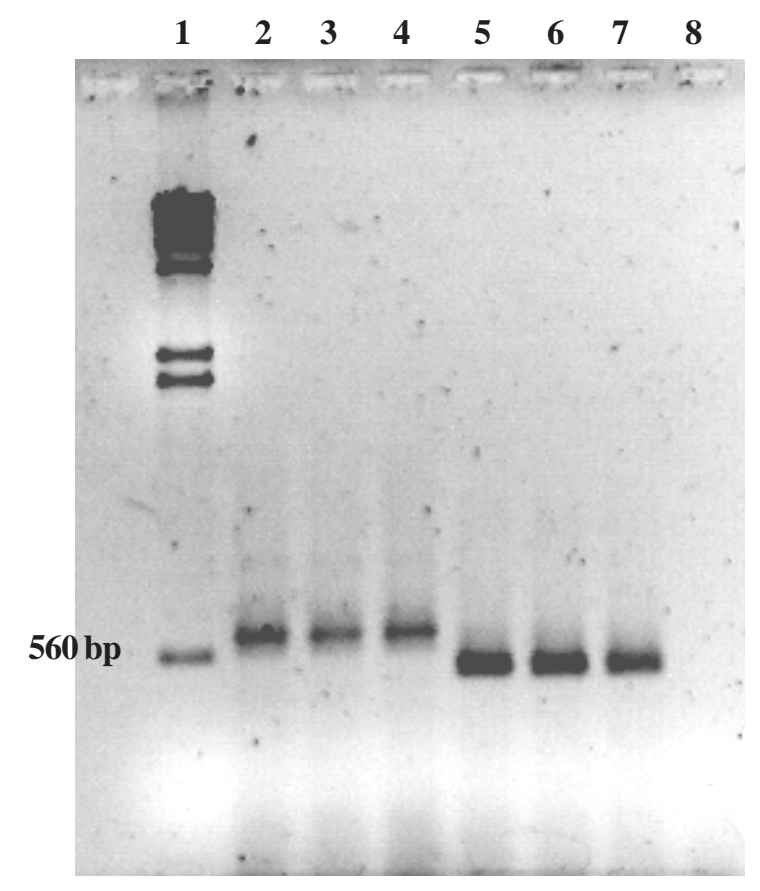

FIG. 1. Produtos de amplificação de PCR com primers ITS 4 e 5 combinados, usando três diferentes extratos crus obtidos de esporo único de fungos micorrízicos arbusculares. Linha 1, marcador molecular $\lambda$ digerido com HindIII; linhas 2 a 4, Acaulospora longula; linhas 5 a 7, Scutellospora gilmorei; linha 8, Controle. 
$\begin{array}{llllllllll}1 & 2 & 3 & 4 & 5 & 6 & 7 & 8 & 9 & 10\end{array}$

$560 \mathrm{bp}$

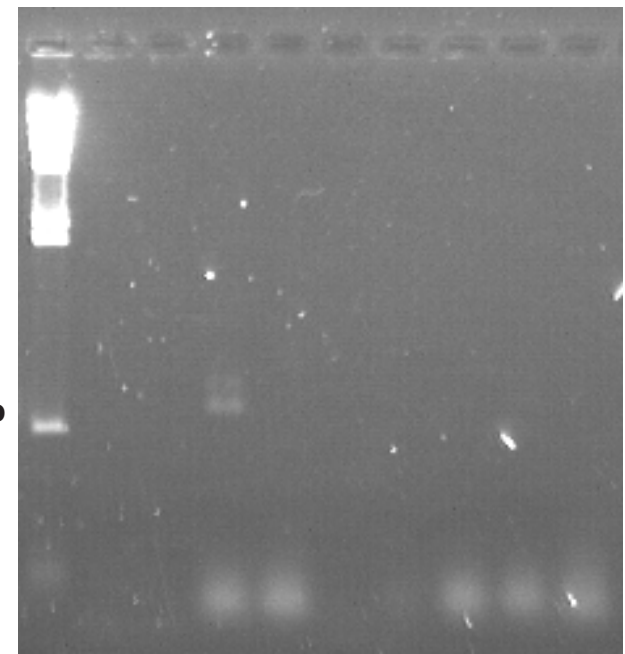

FIG. 2. Produto da amplificação de PCR usando os primers ITS 4 e 5 combinados, obtidos de extrato cru de raízes de cafeeiro colonizadas ou não, em diferentes diluições (vol.:vol.). Linha 1, marcador molecular $\lambda$ digerido com HindIII; linha 2, raízes colonizadas (C) sem diluição; linha 3, C 1:10; linha 4, C 1:100; linha 5, C 1:1000; linha 6, não-colonizada (NC) sem diluição; linha 7, NC 1:10; linha 8, NC 1:100; linha 9, NC 1:1000; linha 10, Controle (sem DNA e sem diluição).

amplificados de A. longula e de raízes colonizadas apresentaram aproximadamente 580 bp. S. gilmorei apresentou segmentos amplificados de aproximadamente $540 \mathrm{bp}$, portanto diferente das raízes colonizadas, o que comprova que $S$. gilmorei não colonizava as raízes do cafeeiro amostradas. Nestas raízes observou-se também uma segunda banda, de peso molecular ligeiramente superior ao observado no A. longula. Raízes não colonizadas e a testemunha sem DNA não apresentaram amplificação.

O cultivo de leguminosas altamente micorrízicas pode aumentar o potencial de inóculo de FMAs no solo, tanto da região do cultivo como também de áreas vizinhas, e isto pode ser particularmente importante em situações de monocultivos permanentes, como é o caso do cultivo do café e de citros. Potencial de inóculo natural do solo é o conjunto de $\begin{array}{llllllllll}1 & 2 & 3 & 4 & 5 & 6 & 7 & 8 & 9 & 10\end{array}$

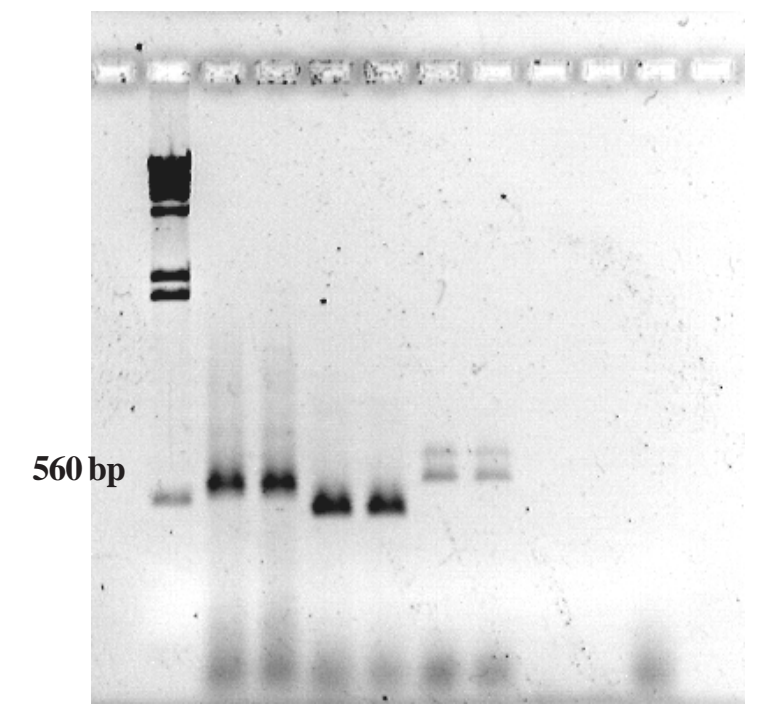

FIG. 3. Produto de amplificação de PCRs obtidos de extrato cru de esporo único de fungos micorrízicos arbusculares e de raízes de cafeeiro colonizadas ou não, usando os primers ITS 4 e 5 combinados. Linha 1, marcador molecular $\lambda$ digerido com HindIII; linhas $2 \mathrm{e}$ 3, Acaulospora longula; linhas 4 e 5, Scutellospora gilmorei; linhas 6 e 7, extrato de raízes colonizadas (dil. 1:100); linhas 8 e 9, extrato de raízes não colonizadas (dil. 1:100); linha 10, Controle (sem DNA e sem diluição).

estruturas fúngicas (esporos, células auxiliares vesículas e fragmentos de hifas) presentes no solo, livres ou associadas à matéria orgânica ou agregados, capazes de infectar plantas, promover colonização radicular e estabelecer micorrizas. Monoculturas prolongadas diminuem o potencial de inóculo natural do solo e a diversidade de espécies de FMAs. Segundo Johnson et al. (1992), monoculturas contínuas têm efeito negativo sobre o potencial de inóculo de FMAs, porque geralmente selecionam espécies mais adaptadas ao agrossistema, mas de eficiência simbiótica menor. Smith (1980) observou redução no potencial de inóculo de FMAs após cultivo permanente com trigo. Entretanto, este efeito se reverteu gradualmente após três rotações na área com pastagens. Baltruschat \& Dehne (1988) relatam efeito semelhante sobre o potencial de inóculo de FMAs em 
solos cultivados continuamente com trigo. Neste trabalho, os autores relatam também que o uso de adubação verde com plantas não-micorrízicas (Brassica napus e Rhaphanus sativus) teve efeito negativo ainda maior sobre o potencial de inóculo de FMAs. Os resultados do presente trabalho mostram que o cultivo de Crotalaria breviflora na entrelinha de plantio do cafeeiro aumentou a densidade de esporos de FMAs, tanto na entrelinha quanto na linha de plantio do cafeeiro. É possível que este aumento na concentração de esporos possibilite também aumentos no potencial de inóculo natural do solo. Entretanto, isto não foi avaliado neste experimento.

Os efeitos de variáveis edáficas, principalmente $\mathrm{pH}$ e disponibilidade de $\mathrm{P}, \mathrm{Ca}$ e $\mathrm{Mg}$, têm sido amplamente citados como importantes sobre a ocorrência de FMAs, sua germinação no solo e colonização de plantas (Siqueira et al., 1989; 1990). Entretanto, a determinação de correlações entre ocorrência de FMAs e estes fatores é difícil. O que se observa nos trabalhos de levantamento são tendências de ocorrências de FMAs em função de algumas variáveis de solo. Por exemplo, Siqueira et al. (1989), estudando a ocorrência de FMAs em agro e ecossistemas, relatam a tendência a ocorrerem espécies de Acaulospora em solos com $\mathrm{pH}$ inferior a 6,5, e comportamento variado em relação ao teor de P disponível. Gigasporas foram observadas em faixa de $\mathrm{pH}$ mais ampla, e menor concentração de $\mathrm{P}$ disponível e Glomus etunicatum ocorreram predominantemente em solos com pH maior que 6,5 e concentração de $\mathrm{P}$ acima de $12 \mathrm{mg} / \mathrm{kg}$.

No presente trabalho não foram observadas relações claras entre as variáveis de solo e a ocorrência de FMAs. Espécies de Glomus diaphanum, por exemplo, tradicionalmente citadas como de baixa tolerância à acidez, ocorreram preferencialmente na rizosfera do cafeeiro, onde o $\mathrm{pH}$ observado foi de 3,9. Por outro lado, Gigasporas, freqüentemente citadas como de ocorrência em solos de maior acidez e baixo P, ocorreram preferencialmente nas parcelas cultivadas com crotalária, onde a acidez do solo observada foi menor ( $\mathrm{pH}=5,1)$. Por outro lado, Acaulosporas foram observadas no cafeeiro e crotalária, independentemente da acidez e do teor de $\mathrm{P}$ disponível, o que confirma sua maior adaptabilidade a diferentes agrossistemas.
Além de características de solo, a compatibilidade entre os simbiontes precisa ser considerada como um fator decisivo para a micorrização e a permanência do fungo no agrossistema. Segundo Abbott \& Robson (1991), a abundância de fungos micorrízicos nos ecossistemas naturais está relacionada ao nível de infecção das raízes das plantas, bem como à abundância de espécies de plantas, o que sugere a ocorrência de associações preferenciais entre fungo e hospedeiro. Costa (1993), estudando soja e milho cultivados em monoculturas ou rotação, observou mudanças quantitativas e qualitativas na comunidade de FMAs relacionadas às plantas hospedeiras. $S$. coralloides, $S$. calospora e $S$. heterogama foram observadas apenas na rizosfera de milho em monocultura, sendo eliminadas do solo quando a soja foi cultivada em rotação. G. ramisporophora foi favorecida pela soja cultivada em monocultura. $A$. longula não apresentou preferência de hospedeiro, e não foi afetada pelo manejo. No presente trabalho foram observadas diferenças qualitativas na ocorrência de FMAs. G. margarita e G. decipiens ocorreram apenas na crotalária, $S$. heterogama, $A$. spinosa, Acaulospora sp., G. diaphanum e A. longula apenas no cafeeiro, sendo este último observado com $36,3 \%$ de freqüência de ocorrência. Por outro lado, A. scrobiculata, $A$. appendicula e $S$. gilmorei foram observadas tanto na crotalária como no cafeeiro cultivado adjacente, e $S$. gilmorei ocorreu com freqüência de $45,3 \%$ na crotalária e $19,3 \%$ no cafeeiro (Tabela 2). A maior diversidade de espécie de FMAs observada no cafeeiro sem adubo verde pode ser explicada pela presença de invasoras que crescem na área, entre uma capina e outra, estimulando FMAs diferentes. Como a maioria destas invasoras são gramíneas, geralmente de sistema radicular agressivo, elas favorecem a micorrização e possibilitam que diferentes espécies de FMAs se mantenham no solo, aumentando sua diversidade.

Por meio da análise de fragmentos de restrição de ITS amplificados pela PCR foi possível saber que $S$. gilmorei, embora presente na rizosfera do cafeeiro, não estava de fato colonizando suas raízes. A análise de fragmentos de restrição de ITS tem sido citada como uma valorosa ferramenta para caracterização de fungos (Gardes et al, 1991; Lee \& Taylor, 1992; Zambino \& Szabo, 1993; Henrion et al., 1994) e também de Glomales, na qualidade de gênero ou espécie (Redecker et al., 1997). Nas Glomales, entre- 
tanto, as seqüências de ITS têm se mostrado em alguns casos heterogêneas, como por exemplo em esporos de G. mosseae (Sanders et al., 1995; LloydMacGilp et al., 1996) e Gigaspora sp. (Redecker et al., 1997). Por isso , tem sido também sugerido o uso de primers de ITS específicos (Abbas et al., 1996). Entretanto, como $S$. gilmorei foi a única Scutellospora observada no cafeeiro, as diferenças no padrão de bandas observadas foram suficientes para se poder concluir que $S$. gilmorei não estava colonizando as raízes do cafeeiro, sem a necessidade de análises complementares usando primers específicos.

No estudo de raízes, testes preliminares das amostras de extrato de raízes de cafeeiro, colonizadas ou não, indicaram a necessidade de diluições e do uso da resina Chelex. Diluições são procedimentos freqüentemente utilizados em PCR para tentar otimizar a relação primer: concentração de DNA, para que os sítios de anelamento se adeqüem a concentração de primers utilizada. Diluiçõos de amostras também são eficientes em eliminar inibições da PCR por substâncias fenólicas, polissacarídeos ou ácidos húmicos, que têm sido freqüentemente encontrados em associação com DNA de tecidos de plantas e associados com inibições da PCR (Egger \& Sigler, 1993; Bentivenga \& Morton, 1994). Chelex é uma resina catiônica capaz de eliminar contaminantes de solo capazes de inibirem a PCR. O uso do Chelex, associado às diluições, foi suficiente para eliminar essas inibições.

Somente A. longula foi detectada em amostras de raízes de cafeeiro contendo $68 \%$ de colonização. A. longula e $S$. gilmorei nunca foram detectadas em segmentos de raízes não-colonizadas e no controle. Produtos não-específicos, entretanto, foram amplificados nas amostras de raízes colonizadas. A presença destes produtos de DNA em raízes colonizadas sugerem a presença de outra espécie de FMAs, ou então, que os primers não foram taxonespecíficos e puderam amplificar DNA nãomicorrízico. Entretanto, essas observações não foram estudadas.

A colonização de raízes do cafeeiro por A. longula, detectada pela PCR, já era esperada devido à alta freqüência de ocorrência de esporos deste fungo observados na sua rizosfera. Entretanto, a não-colonização do cafeeiro por S. gilmorei, evidenciada pela ausência de bandas específicas deste fungo nas raízes do cafeeiro, surpreendentemente indi- ca que $S$. gilmorei, apesar de ocorrer na rizosfera do cafeeiro, não se estabeleceu efetivamente nas suas raízes. É possível que $S$. gilmorei tenha sido introduzida na rizosfera do cafeeiro através das raízes de crotalária ou de invasoras (tratamento controle) crescidas na entrelinha, que se estenderam até a região de crescimento radicular do cafeeiro em busca de maior disponibilidade de P. Entretanto, a hipótese de que $S$. gilmorei esteja presente nas raízes do cafeeiro em concentrações tão baixas que não puderam ser detectadas pela amostragem, precisa ser considerada. Contudo, a ausência de colonização detectável de $S$. gilmorei no cafeeiro mostra sua baixa capacidade competitiva por sítios de colonização na raiz do cafeeiro, em condições de campo.

As evidências de que FMAs multiplicados em C. breviflora estão presentes na rizosfera do cafeeiro, mas não estão efetivamente colonizando suas raízes, mostram a importância de se conhecerem as populações destes fungos que determinada espécie de planta pode estimular, quando se pensa em benefícios do pré-cultivo ou cultivo intercalar como prática de manejo para aumentar o potencial de inóculo natural destes fungos no solo.

É possível que o uso de seqüências de ITS amplificadas de extratos de raízes colonizadas usando PCR e primers específicos para FMAs possibilite a caracterização das populações ativas destes fungos no campo, e permita uma melhor compreensão das relações fungo-planta-solo e sistemas de produção.

\section{CONCLUSÕES}

1. O cafeeiro e a crotalária estimulam populações diferentes de fungos micorrízicos arbusculares na sua rizosfera.

2. A amplificação de fragmentos de DNA através da PCR e primers ITS possibilita a caracterização de fungos micorrízicos na rizosfera e nas raízes do cafeeiro.

3. Técnicas moleculares auxiliam no estudo da dinâmica populacional de fungos micorrízicos arbusculares em agrossistemas.

\section{AGRADECIMENTOS}

Aos pesquisadores Dr. R. Hampp, Dr. U. Nehls e M. Breuninger, do Instituto de Botânica da Eberhard- 
Karls-Universität, Tübingen, Alemanha, pelo auxílio na execução da parte do trabalho relacionada à aplicação das técnicas de biologia molecular aos fungos micorrízicos; à professora Dra. Sandra Maria Gomes da Costa, da Universidade Estadual de Maringá, em Maringá, PR, pela identificacão dos fungos micorrízicos; aos colegas Oswaldo Machinesk, Aresmundinei Dias e Clarice Correia André, funcionários do Laboratório de Microbiologia do Instituto Agronômico do Paraná, pelo auxílio na execução dos trabalhos relacionados ao campo.

\section{REFERÊNCIAS}

ABBAS, D.J.; HETRICK, B.A.D.; JURGENSON, J.E. Isolate specific detection of mycorrhizal fungi using genome specific primer pairs. Mycologia, New York, v.88, n.6, p.939-946, 1996.

ABBOTT, L.K.; ROBSON, A.D. Factors influencing the occurrence of vesicular-arbuscular mycorrhizas. Agriculture, Ecosystems and Environment, Amsterdam, v.35, p.121-150, 1991.

BALOTA, E.L.; LOPES, E.S. Introdução de fungo micorrízico arbuscular no cafeeiro em condições de campo. I. Persistência e interação com espécies nativas. Revista Brasileira de Ciência do Solo, Campinas, v.20, p.217-223, 1996a.

BALOTA, E.L.; LOPES, E.S. Introdução de fungo micorrízico arbuscular no cafeeiro em condições de campo. II. Flutuação sazonal de raízes, de colonização e de fungos micorrízicos arbusculares associados. Revista Brasileira de Ciência do Solo, Campinas, v.20, p.225-232, $1996 \mathrm{~b}$.

BALTRUSCHAT, H.; DEHNE, H.W. The occurrence of vesicular-arbuscular mycorrhizal fungi in agroecosystems. II. Influence of nitrogen fertilization and green manure in continuous monoculture and in crop rotation on the inoculum potential of winter barley. Plant and Soil, Dordrecht, v.113, p.251-256, 1988.

BENTIVENGA, S.P.; MORTON, J.B. Stability and heritability of fatty acid methyl ester profiles of glomalean endomycorrhizal fungi. Mycological Research, Cambridge, Grã-Bretanha, v.98, p.14191426, 1994.

BETHLENFALVAY, G.J.; LINDERMAN, R.G. Mycorrhizae in sustainable agriculture. Madison : American Society of Agronomy, 1992. p.1-25. (ASA Special Publication 54)
BONITO, R.D.; ELLIOT M.L.; DES JARDINS, E.A. Detection of an arbuscular mycorrhizal fungus in roots of different plant species with the PCR. Applied and Environmental Microbiology, Washington, v.61, p.2809-2810, 1995.

COLOZZI FILHO, A. Dinâmica populacional de fungos micorrízicos arbusculares no agrossistema cafeeiro e adubação verde com leguminosas. Piracicaba : ESALQ, 1999. 106p. Tese de Doutorado.

COSTA, S.M.G. da. Fungos micorrízicos arbusculares em monoculturas e rotações de milho (Zea mays L.) e soja (Glycine max (L.) Merrill). Rio Claro : UNESP, 1993. 112p. Tese de Doutorado.

EDWARDS, S.G.; FITTER, A.H.; YOUNG, J.P.W. Quantification of an arbuscular mycorrhizal fungus, Glomus mosseae, within plant roots by competitive polymerase chain reaction. Mycological Research, Cambridge, Grã-Bretanha, v.101, n.12, p.1440-1444, 1997.

EGGER, K.N.; SIGLER, L. Relatedness of the ericoid endophytes Scytalidium vacinii and Hymenoscyphus ericae inferred from analysis of ribosomal DNA. Mycologia, New York, v.85, p.219-230, 1993.

FERNANDES, A.B. Micorrizas vesicular-arbusculares em cafeeiro da região sul do Estado de Minas Gerais. Lavras : ESAL, 1987. 98p. Dissertação de Mestrado.

GARDES, M.; WHITE, T.J.; FORTIN, J.A.; BRUNS, T.D.; TAYLOR, J.W. Identification of indigenous and introduced symbiotic fungi in ectomycorrhyzae by amplification of nuclear and mitochondrial DNA. Canadian Journal of Botany, Ottawa, v.69, p.180190,1991.

GERDEMANN, J.W.; NICOLSON, T.H. Spores of mycorrhizal endogamous species extracted from soil by wet sieving and decanting. British Mycological Society Transactions, Cambridge, Grã-Bretanha, v.46, p.235-244, 1963.

GIOVANNETTI, M.; MOSSE, B. An evaluation of techniques for measuring vesicular arbuscular mycorrhizal infection in roots. New Phytologist, Cambridge, Grã-Bretanha, n.84, p.489-500, 1980.

HENRION, B.; CHEVALIER,G.; MARTIN, F. Typing truffle species by PCR amplification of the ribosomal DNA spacers. Mycological Research, Cambridge, Grã-Bretanha, v.98, p.37-43, 1994.

Pesq. agropec. bras., Brasília, v.35, n.10, p.2033-2042, out. 2000 
JOHNSON, N.C.; COPELAND, P.J.; CROOKSTON, R.K.; PFLEGER, F.L. Mycorrhizae: possible explanation for yield decline with continuous corn and soybean. Agronomy Journal, Madison, v.84, p.387-390, 1992.

LANFRANCO, L.; WYSS, P.; MARZACHI, C.; BONFANTE, P. Generation of RAPD-PCR primers for the identification of isolates of Glomus mosseae, an arbuscular mycorrhizal fungus. Molecular Ecology, Oxford, v.4, p.61-68, 1995.

LEE, S.B.; TAYLOR, J.W. Phylogeny of five fungus-like protoctistan Phytophthora species, inferred from the internal transcribed spacers of ribosomal DNA. Molecular Biology and Evolution, Chicago, v.9, p.636-653, 1992.

LLOYD-MACGILP, A.S.; CHAMBERS, S.M.; DODD, J.C.; FITTER, A.H.; WALKER, C.; YOUNG, J.P.W. Diversity of the ribosomal internal transcribed spacers within and among isolates of Glomus mosseae and related mycorrhizal fungi. New Phytologist, Cambridge, Grã-Bretanha, v.133, p.103111,1996

LOPES, E.S.; OLIVEIRA, E.; DIAS, R.; SCHENCK, N.C. Occurrence and distribution of vesicular-arbuscular mycorrhizal fungi in coffee e (Coffea arabica L.) plantations in central São Paulo State, Brazil. Turrialba, San José, v.33, n.4, p.417-422, 1983.

MORTON, J.B.; BENNY, G.L. Revised classification of arbuscular mycorrhizal fungi (Zygomycetes): a new order, Glomales, two new suborders, Glominae and Gigasporinae, and two new families, Acaulosporaceae and Gigasporaceae, with an emendation of Glomaceae. Mycotaxon, Ithaca, v.37, p.471-491, 1990.

PHILLIPS, J.M.; HAYMAN, D.S. Improved procedures for clearing roots and staining parasitic and vesiculararbuscular mycorrhizal fungi for rapid assessment of infection. British Mycological Society Transactions, Cambridge, Grã-Bretanha, v.55, n.1, p.158-160, 1970.

REDECKER, D.; THIERFELDER, H.; WALKER, C.; WERNER, D. Restriction analysis of PCR-amplified internal transcribed spacers of ribosomal DNA as a tool for species identification in different genera of the order Glomales. Applied and Environmental Microbiology, Washington, v.63, n.5, p.1756-1761, 1997.

Pesq. agropec. bras., Brasília, v.35, n.10, p.2033-2042, out. 2000
SANDERS, I.R.; ALT, M.; GROPPE, K.; BOLLER, T.; WIEMKEN, A. Identification of ribosomal DNA polymorphisms among and within spores of the Glomales: application to studies on the genetic diversity of arbuscular mycorrhizal fungal communities. New Phytologist, Cambridge, GrãBretanha, v.130, p.419-427, 1995

SCHENCK, N.C.; PEREZ, Y. Manual for the identification of VA mycorrhizal fungi. Gainesville : University of Florida, 1987. 242p.

SIQUEIRA, J.O.; COLOZZI FILHO, A. Micorrizas vesículo-arbusculares em mudas de cafeeiro. II. Efeito do fósforo no estabelecimento e funcionamento da simbiose. Revista Brasileira de Ciência do Solo, Campinas, v.10, p.207-211, 1986.

SIQUEIRA, J.O.; COLOZZI FILHO, A.; OLIVEIRA, E. Ocorrência de micorrizas vesicular-arbusculares em agro e ecossistemas do Estado de Minas Gerais. Pesquisa Agropecuária Brasileira, Brasília, v.24, n.12, p.1499-1506, dez. 1989.

SIQUEIRA, J.O.; ROCHA JÚNIOR, W.F.; OLIVEIRA, E.; COLOZZI FILHO, A. The relationship between vesicular-arbuscular mycorrhiza and lime: associated effects on the growth and nutrition of brachiaria grass (Brachiaria decumbens). Biology and Fertility of Soils, Berlin, v.10, p.65-71, 1990.

SMITH, T.F. The effect of season and crop rotation on the abundance of spores of vesicular-arbuscular (VA) mycorrhizal endophytes. Plant and Soil, Dordrecht, v.57, p. 475-479, 1980.

STEFFAN, R.J.; ATLAS, R.M. Polymerase chain reaction: applications in environmental microbiology. Annual Review of Microbiology, Palo Alto, v.45, p.137161, 1991.

ZAMBINO, P.J.; SZABO, L.J. Phylogenetic relationships of selected cereal and grass rusts based on rDNA sequence analysis. Mycologia, New York, v.85, p.401-414, 1993.

ZEZE, A.; HOSNY, M.; GIANINAZZI-PEARSON, V.; DULIEU, H. Characterization of a highly repeated DNA sequence (SC1) from the arbuscular mycorrhizal fungus Scutellospora castanea and its detection in plants. Applied and Environmental Microbiology, Washington, v.62, p.2443-2448, 1996. 